\title{
Recent U.S. and International Assessment of Baltic Security Developments
}

\author{
Bert Chapman ${ }^{1^{*}}$ \\ ${ }^{1}$ Purdue University Libraries and School of Information Studies
}

\begin{abstract}
OBJECTIVES: The aim of this paper is to analyse Baltic security developments from U.S. government and military resources, scholarly journal articles, and multinational public policy research institute assessments.
\end{abstract}

METHODS: The aim is to analyse the content and rhetoric within these resources to learn how those producing these materials view Baltic security developments and their viewpoints on how the U.S. and its allies should respond to these developments focusing on increasing Russian regional assertiveness.

RESULTS: The author provides interpretations of Baltic security developments, Russian Baltic policy, and U.S. and NATO responses to these developments in materials produced by U.S. civilian and military policymakers and multinational scholarly analysis. Includes performance assessments of U.S. programs including the European Deterrence Initiative and potential Russian military activity in the Baltics as reflected in varying reports by the U.S. Government, military, and multinational public policy research institutions.

CONCLUSIONS: In conclusion, the author recommends that U.S. and NATO countries recognize a new Cold War exists with a revisionist Russia and also advocates continuing NATO military exercises, upgrading civilian and military infrastructure protection, and enhancing U.S. and allied preparedness. The author also urges ongoing and candid dialogue between NATO and Russia to keep this situation from erupting into war. Insists the U.S. and its allies adroitly

* Corresponding author: chapmanb@purdue.edu

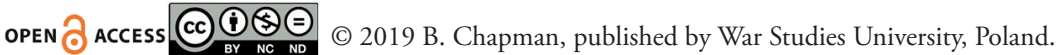

This work is licensed under the Creative Commons Attribution-NonCommercial-NoDerivatives 4.0 License. 
respond to Russian attempts to influence and manipulate public opinion toward Moscow. Finally, the author expresses concern that U.S. partisan division over the 2016 Russian interference in the U.S. presidential election makes achieving greater Baltic policy cohesion difficult. Advocates warning Russia of devastating consequences of attempts to militarily invade or subvert Baltic countries.

Keywords: European Deterrence Initiative, Baltic Security, geopolitics, Russia, European security, U.S. national security policy, NATO security policy

\section{Introduction}

Throughout its history the Baltic Sea region has been a source of extensive international trade and geopolitical importance (North and Kronenberg 2016). Countries surrounding the Baltic include Finland, Sweden, Denmark, Germany, Poland, Russia, Estonia, Latvia, and Lithuania and these countries and Iceland and Norway are members of the Council of Baltic Sea States (U.S. Department of State, Bureau of Intelligence and Research, 1973, Council of the Baltic Sea States 2017, Kyle 2018, pp. 104-115). Following World War I, Estonia, Latvia, and Lithuania enjoyed two decades of independence before the cataclysm of World War II saw these three countries absorbed by the former Soviet Union until they regained their independence in 1990. These countries have made steady economic and social progress becoming integrated into western political structures including the NATO alliance in 2004 (North and Kronenberg, Giguère 2007, North Atlantic Treaty Organization 2017).

However, recent years have seen a reassertion of Russian nationalism under President Vladimir Putin which has sought to test NATO's resolve to defend its strategic interests. Russia's 2007 cyber attack against Estonia (McGuiness 2017, Herzog 2011, pp. 49-60), its intervention in Georgia in 2008, the forcible annexation of Crimea from Ukraine in 2014 (Kuhn 2018), and aggressive Russian flyovers by two Russian Sukhoi Su-24 and a KA-28 Felix helicopter against the U.S. Navy's guided missile destroyer USS Donald Cook in the Baltic on April 11-12, 2016 has made the Baltics an increasingly important area of political emphasis, financial commitment and security interest for the U.S. over the last five years (U.S. Navy 2016, pp. 1-2, Milevski 2018, U.S. Congress, House Committee on Foreign Affairs, Subcommittee on Europe, Eurasia, and Emerging Threats 2017, Scheer 2019, pp. 10-17, Béraud-Sedreau and Giegerich 2018, 53-74). Increasing U.S. Government and military interest in and international scholary analysis 
of Baltic Sea security topics is reflected in governmental rhetoric, political debate, financial investment, and public policy research institute literature since 2014 and will now be examined. This work hypothesizes that American governmental and military policy research analysis can provide beneficial guidance to those studying Baltic security matters. It recognizes that the content of this rhetoric and literature can be limited by partisan political bias and analytical and methodological deficiencies in such research. This article reflects a realist perspective and recommendations supportive of a more assertive U.S. and NATO posture toward Russian activity in this region based on governmental, military, and public policy research institute analysis of Baltic security matters.

Presidential Rhetoric-Presidential statements and proclamations are often authoritative indicators of U.S. policy stances on public policy issues coming from the U.S. Government's most senior leadership. Meeting with Estonian President Toomas Hendrik Ilves in Tallinn on September 3, 2014, former President Barack Obama stressed the importance of the U.S.' NATO commitment to the Baltic countries, praised Estonian soldiers service in Afghanistan, the Central African Republic, and Iraq, and noted his administration was working with Congress to increase the U.S. Baltic military presence including bringing additional Air Force units and aircraft to the Nordic-Baltic region for training purposes (The President's News Conference with President Toomas Hendrik Ilves... 2014, pp. 1,3).

In a May 13, 2016 White House meeting with Nordic leaders, Obama claimed:

"We are united in our concern about Russia's growing aggressive military presence and posture in the Baltic-Nordic region. We will be maintaining ongoing dialogue and seek cooperation with Russia, but we also want to make sure that we are prepared and strong, and we want to encourage Russia to keep its military activities in full compliance with international obligations" (Joint Statement of the United States-Nordic Leaders Summit ... 2016, pp. 1-2). In their joint statement, these leaders reaffirmed their support for the Baltic States interest to strengthen regional security and stability and to leverage their collective capacities to withstand Russian hybrid threats and enhance political, economic, and military assets for strengthening national and regional resilience (Joint Statement of the United States-Nordic Leaders Summit... 2016, p. 1).

This support for Baltic security continued into the Trump Administration. Attending NATO's July 2016 summit in Warsaw, Trump praised Poland's historic and contemporary 
role in defending European freedom, lauded Poland's decision to purchase the U.S.' Patriot air and missile defense system, and urged NATO countries to meet their financial obligations to militarily support NATO security during a speech in Krasiński Square. One analysis of this speech stressed the symbolic importance of it being made at the site of the monument to the 1944 Warsaw Uprising, the importance of Poland and the Baltic Sea Region to European security, reaffirming the U.S. commitment to NATO, and reminding Russia of the U.S.' awareness of this region's history (Remarks in Warsaw, Poland... 2017, pp. 1-7, Thieme 2018, pp. 149-153).

Trump's support for Baltic security was reaffirmed during an April 3, 2018 White House meeting with Baltic Presidents Kersti Kaljulaid of Estonia, Rajmonds Vejonis of Latvia, and Dalia Grybauskaite of Lithuania. This meeting saw Trump announce that the U.S. intended to provide nearly $\$ 100$ million for these countries to purchase large-caliber ammunition; over $\$ 70$ million in training and equipping programs to enhance these countries military force national capacity building; and that more than 5,000 U.S. forces will join multinational forces participating in the Baltic region's 2018 Saber Strike exercise. Additional summit actions include the U.S. seeking to enhance Baltic energy infrastructure by providing expertise to prevent, detect, thwart, and recover from hostile cyberattacks; offering technical assistance to support energy diversification projects including synchronizing Baltic and European electric grids; providing $\$ 3$ million to enable the Baltic countries to build public and institutional resiliency against disinformation by strengthening independent media outlets, public service broadcasters, and regional media literacy skills; and also promoting the centennial of Estonian, Latvian, and Lithuanian independence through various educational and exchange programs (Joint Statement: A Declaration to Celebrate A 100 Years of Independence... 2018, pp. 1-3, McNamara 2017, pp. 73-98).

\section{Congressional Action}

The U.S. Congress is also a major partner in U.S. Baltic regional policy through its debates, legislative, funding, and oversight responsibilities deriving from Article 1 of the U.S. Constitution (Chapman 2016, pp. 85-86). Congress seeks to influence U.S. policy through resolutions, debates, legislation, holding oversight hearings, and approving funding and requiring federal agencies to report on activities implementing 
congressionally enacted legislation. On June 4, 2015, Senator Lisa Murkowski (R-AK) expressed concern over the existing law prohibiting U.S. petroleum exports at a time when U.S. domestic energy production was increasing, recent incidents of Russian energy coercion against Europe such as Russia cutting off natural gas to Ukraine and other Eastern European countries in January 2009, and the dependence many NATO countries have on Russia for oil and natural gas resources (Congressional Record 2015 p. S3766). An example of Congress expressing its displeasure with Russian aggression was Senate Resolution 501 introduced on June 28, 2016 which criticized the overflights of the USS Donald Cook, and a Russian SU-27 fighter doing a barrel roll over a U.S. reconnaissance aircraft flying in international airspace over the Baltic on April 14, 2016 while calling on Russia to cease provocative military maneuvers endangering U.S. and allied military forces (S. Res. 501 2016).

Witnesses testifying at a June 23, 2016 briefing held by the Commission on Security and Cooperation in Europe (CSCE) noted a recent groundbreaking ceremony that began construction of an Aegis ballistic missile defense base in Redzikowo, Poland, a quadrupling of the European Reassurance Initiative's (ERI) budget, the concern expressed over Russian military aircraft not turning their transponders on during interactions with western military aircraft, the belief expressed that Finland and Sweden could join NATO tomorrow if they chose to, and that over 20 European nations planned to increase their defense spending stemming from increasing Russian aggressiveness (U.S. Commission on Security and Cooperation in Europe 2016, pp. 4, 7, 16, 18, 21).

A July 7, 2016 Senate Armed Services Committee hearing saw Senator John McCain (R-AZ) comment that NATO had deployed a Rapid Reaction Force, increased air policing and sea patrols, and moved more forces and equipment toward the Baltic Sea states while expressing anger that some European officials had criticized these measured responses as being "saber-rattling or warmongering." Witness Julianne Smith of the Center for a New American Security stressed that there would be more Russian military air and sea probing in the Nordic-Baltic Region and beyond and thought Vladimir Putin would be emboldened to engage in additional coercive acts if he saw the EU and NATO as weak and unraveling, and that the U.S. needed to bolster deterrence, reassure allies, and send a stronger signal to Putin about the alliance's collective resolve (U.S. Congress, Senate Committee on Armed Services 2017, pp. 4, 25).

A December 7, 2016 CSCE briefing saw Rand Corporation witness Michael Johnson note former NATO Supreme Allied Commander General Philip Breedlove stating that 
"Russia has chosen to be an adversary and imposes a long-term existential threat to the United States and our European allies and partners." Johnson also stressed that a long supply chain of over 5,000 miles by sea for the U.S. has to provide military reinforcement in Eastern Europe; stressed that the U.S. Army has only nine brigades which are U.S.-based and fewer than the number of U.S. aircraft carriers; and that Russian long-range surface-to-air missiles, submarines, and anti-ship missiles make it too dangerous to directly deploy forces to the Baltics. He stressed that getting these forces from Germany to the battlefield is problematic due to insufficient Eastern European transportation infrastructure for battle tanks and that there are insufficient logistic hubs for fuel, ammunition, spare parts, and medical services with these Germany-based services designed to sustain combat from 100 miles during the Cold War.

He stressed that despite the Ukrainian conflict and a poor readiness rate, Russia could still generate 26 battalion tactical groups in their Western Military District with three to seven days warning. Johnson concluded by saying that NATO's chances could be improved by adding three armored brigades to four infantry brigades capable of fighting at short warning to change combat outcomes. An effect of this would enable these forces to delay a Russian advance, retreat to defend national capitals, and use existing stocks of ammunition and fuel to give time for NATO reinforcements to provide assistance (U.S. Commission on Security and Cooperation in Europe 2017, pp. 5, 7, 9).

During a March 1, 2017 House Armed Services Committee subcommittee hearing, Rep. Michael Turner (R-OH) noted that Joint Chiefs of StaffChairman General Joseph Dunford had said "Russia represents the greatest threat to our national security... [what] they seek to do is to undermine the credibility of our ability to meet our alliance commitments to NATO.” Witness Andres Hunter of the Center for Strategic and International Studies (CSIS) stressed the operational and tactical challenges of Russian Anti-Access Aerial Denial (A2/AD) capabilities to U.S. ground forces, noted that substantial Russian investment in ground combat systems narrows the U.S. advantage in this area and that Moscow has gained pre-eminence in artillery and rocket systems. He noted such advanced capabilities, combined with shorter internal Russian communication lines, also challenge U.S. ground forces; and Russian non-kinetic capabilities in electronic warfare, cyber operations, and information operations significantly transcend U.S. Army capabilities in a potential conflict and potentially undermine U.S. intelligence and anti-armor system effectiveness threatening the U.S.' and NATO's ability to operate effectively as a coalition 
(U.S. Congress, House Committee on Armed Services, Subcommittee on Tactical Air and Land Forces 2017, pp. 1, 7-8).

A March 22, 2017 House Foreign Affairs Committee subcommittee hearing saw Rep. Brad Sherman (D-CA) maintain that Baltic countries should spend $4 \%$ of their Gross Domestic Product (GDP) on defense while complaining that only one Baltic state meets the NATO requirement of spending 2\% of GDP on defense. Witness Paul Goble of the Institute of World Politics maintained that Russia would not send its tanks over the Baltic countries borders as long as they are part of NATO, while also stressing the importance of these countries successfully integrating Russian ethnic minorities into their societies. Conversely, witness Lisa Sawyer Stamp of CSIS stressed that the U.S.' European combat presence was a full brigade strength below what it was during 2012, that NATO's largest post-Cold War exercise included 30,000 troops, and that Russia's planned Zapad exercise in 2017 could include up to 200,000 personnel (U.S. Congress, House Committee on Foreign Affairs, Subcommittee on Europe, Eurasia, and Emerging Threats 2017, pp. 5, 7-8, 14).

A March 28, 2017 House Armed Services Committee hearing on Russian military activities and European security challenges saw committee Chair Rep. Mac Thornberry (R-TX) assert: Meanwhile the Russians continue to invest in their nuclear weapons, their anti-access/aerial denial capability, and in a variety of other capabilities de signed to reduce or eliminate any technological military advantage that the United States may have had in the past. We know that one of their primary goals is to divide and weaken NATO....arguably the most successful military alliance ever (U.S. Congress, House Committee on Armed Services 2017, p. 1).

U.S. European Command (EUCOM) commander General Curtis Scaparroti stressed that EUCOM had identified intelligence, surveillance, and reconnaissance (ISR) collection platforms to improve timely threat information and strategic warning, land force capabilities to deter further Russian aggression, enhanced naval capabilities for antisubmarine warfare; pre-positioned equipment to increase crisis responsiveness; and enhanced missile defense systems as critical focus areas. Scaparotti also told this committee's ranking member Rep. Adam Smith (D-WA) that the U.S. needed greater forces there including a rotational or rotational enduring land footprint such as an armored division; stressed the Air Force's posture was very capable but needed fifth generation aircraft; and that the Navy needed to upgrade its antisubmarine warfare capabilities (U.S. Congress, House Committee on Armed Services 2017, pp. 3-5). 
Congressional discussion and analysis of Baltic security matters can also occur through legislation and debate on the House and Senate floors. On March 28, 2017, Rep. John Shimkus (R-IL) noted concerns that Baltic countries had about a nuclear power plant being constructed in Belarus and run by Rosatom, the state-owned Russian nuclear company. Shimkus stressed that Belarus had ignored four of the six reviewed steps recommended by the International Atomic Energy Agency to prevent nuclear disasters like Chernobyl and Fukushima, that Belarus and Lithuania are Espoo Convention signatories which calls for member states to consult with bordering countries about such projects, allow experts to review project information, and share information with bordering countries about the safety and security of these projects. The plant is 12.5 miles from the Lithuanian border and in sight of Vilnius. Nearly all of Lithuania is within 186 miles of this plant and would be affected if a disaster occurred such as contamination spilling into the Neris River which is a key Lithuanian water supply source. Shimkus also criticized Belarus for not telling Lithuania about four accidents which occurred at this plant during 2016, including a 330-ton nuclear reactor shell being dropped from a height of 13 feet (Congressional Record 2017, p. H2468, Stravers 2018, pp. 541-556).

In comments inserted into the Congressional Record on May 18, 2017, Rep. Christopher Smith (R-NJ) criticized Russia for violating central commitments of the Helsinki Final Act including the territorial integrity of states and noting that Russian aggression is not geographically restricted but threatens the entire region. He emphasized that Russia has forcefully seized sovereign territory, threatened to use tactical nuclear weapons against other countries, harassed U.S. and NATO military assets, and abandoned key transparency measures and commitments. Smith praised the ERI which has seen NATO members hold over 1,000 military exercises since 2014 and enabled U.S. forces to participate more actively in these exercises and urged continued enhancement of NATO's conventional deterrent in Poland and the Baltic States (Congressional Record 2017, pp. E669-670).

June 7, 2017 saw a bipartisan group of four Representatives introduce H.R. 2820 the Fight Russia Corruption Act which was referred to the House Foreign Affairs and Intelligence Committees. This legislation stressed how countries adjoining Russia were threatened by Moscow's military aggression and hybrid warfare strategy of using direct and indirect action to coerce, destabilize, and exert malign influence over them. It called for creating an Office of Anti-Corruption Relating to Russian Financial Activities in 
Europe within the State Department. Additional provisions of this proposed legislation called for analyzing Russian financial networks operating in European countries with investments in real estate, energy, media, and other sectors, elevating anti-corruption as an element of NATO's Readiness Action Plan, requiring NATO's Assistant Secretary General for Intelligence and Warning to monitor Russian influence in NATO member states, and prioritizing combating Russian influence in the NATO-European framework. It would also require the Director of National Intelligence to prepare a National Intelligence Estimate on purchases made by individuals and organizations of key European sectors providing monopolistic control of a sector and detailed analysis of individuals and organizations making such purchases including their revenue sources and links to the Russian Federation. This legislation was not enacted during the 116th Congress (2017-2018) although it had 22 House co-sponsors at the end of 2017 (H.R. 2820, 115th Congress, 1st Session, History of Bills 2017).

During a June 28, 2017 Senate Intelligence Committee hearing, witness Nicholas Burns of Harvard's Kennedy School of Government, noted that Russia was seeking to expand its influence over its neighbors and reduce global U.S. power and influence by seeking to manipulate elections in many countries and consistently harassing NATO allies including Estonia, Latvia, and Lithuania. This hearing also saw Janis Sarts of NATO's Strategic Communications Center of Excellence note that Russian election meddling involved financing pro-Russian candidates and political parties by offering Kremlin media as a platform in Estonia's 2009 European Parliament elections, by conducting cyber attacks against candidates Russia perceives as hostile, and engaging in malicious disinformation using social media bots and pro-Kremlin media outlets. Sarts also maintained that Baltic countries were particularly concerned about the Russian military's 2017 Operation Zapad exercises (U.S. Congress, Senate Select Committee on Intelligence 2017, pp. 7, 31, 70, 80-82, Kragh and Åsberg 2017, pp. 777-816).

\section{US/NATO Countervailing Actions}

Concern over possible Russian irredentism toward the Baltic countries has been prevalent for many years and reflected in NATO policymaking. NATO Air Policing seeks to maintain the airspace of NATO alliance members. Contributions come from all member countries and include national air surveillance systems, air traffic management, 
interceptor aircraft, and other air defence measures. This policing involves the use of the Air Surveillance and Control System (ASACS) and appropriate Quick Reaction Air intercept of fast jets. This policing responds to military or civilian aircraft in distress and to aircraft not following international flight regulations and approaching NATO airspace. These Air Policing facilities are based at Uedem, Germany, and Torrejon, Spain (North Atlantic Treaty Organization 2019b, pp. 1-3).

NATO has also developed an Enhanced Forward Presence (EFP) consisting of four multinational battle groups in Estonia, Latvia, Lithuania, and Poland. Leadership of these battle groups is provided by Canada, Germany, the United Kingdom, and United States. These entities are multinational and combat ready and seek to demonstrate that an attack against one NATO member is an attack against all NATO members while also representing the largest collective NATO collective defence reinforcement in a generation (North Atlantic Treaty Organization 2019a, p. 1).

NATO's Response Force (NRF) was created in 2002 and is a technologically advanced, multinational force consisting of rapidly deployable land, air, maritime, and Special Operations Forces. The NRF provides a collective defence and rapid military response to an emerging crisis, execute peace-support operations, protects critical infrastructure, and supports disaster relief. It is based at Brunssum, the Netherlands and Naples, Italy and its four components include a Command and Control Element; Very High Readiness Joint Task Force (VJTF), an Initial Follow on Forces Group capable of deploying quickly following the VJTF in response to a crisis, and a Response Forces Pool (RFP) featuring multispectrum military capabilities including command and control, combat, and support units from a wider pool of national military forces. A Spearhead Force was created in NRF following the 2014 Wales Summit to better respond to the changing security environment on NATO's eastern and southern borders (North Atlantic Treaty Organization 2018).

An additional component of NATO's response to potential Russian caused security contingencies in the Baltic is the $30 / 30 / 30 / 30$ plan. This would require NATO to have 30 land battalions, 30 air fighter squadrons, and 30 ships ready to deploy within 30 days of being put on alert. This plan was established at the February 2018 NATO summit in Brussels with the intention of answering U.S. criticisms that NATO members do not have sufficient capabilities to counter Russia and to develop a war plan for countering Russia (Emott and Ali 2018, Muñoz 2019). 


\section{European Reassurance/Deterrence Initiative}

U.S. policymakers in Congress and the executive branch responded to Russian aggression in eastern Europe by enacting the European Reassurance Initiative (ERI) in 2014 which has become the European Deterrence Initiative (EDI). This statute authorized the Secretary of Defense to spend up to $\$ 1$ billion for the following purposes:

1. Increasing the presence of U.S. armed forces in Europe.

2. Bilateral and multilateral military exercises and training with European allies and partner nations.

3. Improving European infrastructure to enhance U.S. military responsiveness.

4. Enhancing the European prepositioning of U.S. armed forces equipment.

5. Building the defense and security capacity of European allied and partner nations (Public Law 113-291 2014, p. 3618, Mölder 2011, pp. 143-168).

An August 22, 2017, a Department of Defense Inspector General (DODIG) report on ERI determined that ERI funds augment country military capacity building and enhance interoperability and responsiveness, but risk sustainability since support for ERI imposes new requirements on EUCOM without an equivalent increase in force authorization, and stresses diminishing personnel resources. Such fundsare budgeted as Overseas Contingency Operations (OCO) which only last one year in contrast to DOD's five year Future Years Defense Programming planning cycle identifying immediate base budget priorities and future projections for the next four fiscal years. Consequently, EUCOM and Operation Atlantic Resolve (OAR) countries may be unable to sustain ERI contributions to allied and partner military capabilities (U.S. Department of Defense, Office of Inspector General 2017, pp. 7, 11).

Baltic country specific funding requests made by DOD include enhancing intelligence interoperability and readiness and include intelligence, surveillance, and reconnaissance. ERI funds have also pay travel costs of National Guard instructors and enable Maryland National Guard personnel to train Estonian soldiers to direct NATO and U.S. fighter aircraft against enemy targets, and improving the flow of military equipment and supplies across European national borders. These funds also support Baltic country training with anti-tank weapons, surveillance systems, and forward air-control procedures for fighter aircraft in Estonia, and providing \$11 million for 2016's Operation Saber Strike in the Baltics (U.S. Department of Defense, Office of Inspector General 2017, pp. 13-17, Ǎtland 2016, pp. 163-176). 
Recommendations from the DODIG report for improving ERI's effectiveness include:

1. The Director of the Joint Staff assessing competing mission and personnel priorities of the ERI to determine whether EUCOM and subordinate commands have sufficient personnel resources to execute ERI's mission.

2. The Office of the Deputy Secretary of Defense developing options for changes to the ERI budgeting cycle to better align with and support allied and partner-nation training and capacity-building activities.

3. EUCOM's Commander consider developing and establishing command process to assess the impact of ERI funds on exercises, training, infrastructure improvement, and activities supporting building allied and partner capacity.

4. EUCOM's Commander integrating the newly deployed U.S. Armored Brigade Combat Team and the four NATO Enhanced Forward Presence Battalions into OAR countries exercises and training to ensure ongoing ERI collaboration and interoperability.

5. Complete theater-wide operations plans to inform decisions for ERI support to fill training gaps in OAR countries national training plans and convey a coordinated and unified message to allied and partner countries (U.S. Department of Defense, Office of Inspector General 2017, pp. 20-21, 38, 46-47).

Additional critical assessments of ERI were provided by Congress' Government Accountability Office (GAO) in December 2017 and January 2018. The December 2017 report determined that DOD had not prioritized ERI-funded posture initiatives against those in its base estimate; estimated their sustainment costs; or communicated future costs to Congress. GAO maintained that DOD has not used existing processes to plan for fund ERI posture initiatives; and that it does not communicate to Congress future costs of enduring ERI activities through OCO with DOD contending that providing such costs is outside its budgeting and programming processes (U.S. Government Accountability Office 2017, pp. 11-20).

GAO recommendations to DOD in this report include:

1. DOD prioritizing ERI posture initiatives relative to those funded in its base budget relative to established posture planning processes.

2. DOD directing EUCOM and military services to develop estimates for sustaining prepositioned equipment and other ERI infrastructure projects and ensure the services plan for these long-term costs in future budgets. 
3. DOD providing Congress in its annual budget submission with estimates of future costs for ERI posture funded initiatives and other enduring costs including level of host nation support and burden sharing (U.S. Government Accountability Office 2017, p. 21).

The January $2018 \mathrm{GAO}$ report stressed the role of OCO funding in military operations. It mentioned that the Army separately tracks OCO funds designated for base requirements through its financial system and that ERI funds are issued separately and can only be reported as obligated for the purpose issued. Similar use and tracking of OCO funds also occurs in other U.S. armed service branches (U.S. Government Accountability Office 2018, p. 17).

The Fiscal Year (FY) 2018 (October 1, 2017-September 30, 2018) budget request for ERI was $\$ 4.8$ billion as opposed to $\$ 3.4$ billion for FY 2017. Elements of EUCOM's plan to implement ERI include:

- Increased Presence ( $\$ 1.732 .7$ billion)-Proposing a more robust U.S. European presence for defense and deterrence.

- Exercises and Training (\$217.7 million)-Increasing training to improve Alliance and partner forces readiness and interoperability.

- Enhanced Prepositioning (\$2.221.8 billion)-Strategically placing assets allow EUCOM to more efficiently conduct daily activities while also supporting rapid in theater force deployment.

- Improved Infrastructure (\$337.8 million)-Facilitating infrastructure improvements expanding readiness and U.S. actions and priorities.

- Building Partnership Capacity (\$267.3 million)-Improving operations with allies and partners strengthening their ability to defend themselves (U.S. European Command 2017, p. 1).

ERI became the European Deterrence Initiative (EDI) as a result of Public Law 115-91 the FY 2018 National Defense Authorization Act (Public Law 115-91 2017, p. 1283). In its FY 2019 congressional budget submission, DOD requested $\$ 6.531 .4$ billion for EDI reflecting increasing concern over countering Russian security threats and reflecting the Trump Administration's emphasis on great power competition instead of counterterrorism prompting DOD defense force structure and decision making. The FY 2020 congressional budget submission saw DOD request $\$ 5.910 .6$ billion for EDI representing incremental spending increases for this initiative (U.S. Department of Defense, Office of the Undersecretary of Defense (Comptroller) 2019, p. 1, 
U.S. Department of Defense 2018, pp. 2-4, U.S. European Command 2017, p. 1, U.S. European Command 2019, p. 1).

This document called for EUCOM supporting an average approximate active, reserve, and National Guard personnel strength of approximately 9,903 with 9,095 Army, 350 Navy, and 458 Air Force personnel. These will participate in multiple theater activities including temporary presence or strengthening allied/partner capacity during planned exercises, expanding the size and scope of planned exercises for enhancing NATO interoperability, and supporting EUCOM's Joint Exercise Program and Joint MultiNational Readiness Center training events.

Additional budget requests amounts contained in this document for Baltic relevant applications include:

Table 1. Military Construction, Army-Provides details for congressional oversight and funding of these programs and enhancing public awareness of U.S. spending on Baltic security matters

\begin{tabular}{|l|l|l|}
\hline Staging Area & Zagan, Poland & \$1 million \\
\hline Rail Extension \& Railhead & Powidz, Poland & $\$ 14$ million \\
\hline Ammunition Storage Facility & Powidz, Poland & $\$ 52$ million \\
\hline Rail Extension \& Railhead & Swietoszow, Poland & $\$ 6.4$ million \\
\hline Bulk Fuel Storage & Powdidz, Poland & $\$ 21$ million \\
\hline
\end{tabular}

Table 2. Military Construction, Defense-Wide-Provides details for congressional oversight and funding of these programs and enhancing public awareness of U.S. spending on Baltic security matters

\begin{tabular}{|l|l|l|}
\hline $\begin{array}{l}\text { Special Operations Forces (SOF) } \\
\text { Operations Facility }\end{array}$ & Ämari, Estonia & $\$ 6.1$ million \\
\hline SOF Training Facility & Ämari, Estonia & $\begin{array}{l}\text { \$9.6 million (U.S. Department of } \\
\text { Defense, Office of the Undersecretary } \\
\text { of Defense (Comptroller) 2018, p. 25, } \\
\text { Hunzecker 2016, pp. 12-18). }\end{array}$ \\
\hline
\end{tabular}

Table 3. Additional ERI force enhancements broken down by armed service branches and geographic location in this budget request include:

\begin{tabular}{|l|l|l|}
\hline Increased Presence & $\begin{array}{l}\text { Persistent presence of air, land, and } \\
\text { sea forces in Europe-NATO Article 5 } \\
\text { Commitment }\end{array}$ & $\$ 1.874 .7$ billion \\
\hline Army Rotational Forces & $\begin{array}{l}\text { Ensures U.S. presence across Eastern } \\
\text { Europe including Baltic States }\end{array}$ & $\$ 921.3$ million \\
\hline
\end{tabular}




\begin{tabular}{|c|c|c|}
\hline Army Aviation Rotation & $\begin{array}{l}\text { Supporting Combat Aviation Brigade } \\
\text { including an Armed Reconnaissance (AH- } \\
\text { 64) and Assault Battalion (UH-60) }\end{array}$ & $\$ 100.1$ million \\
\hline $\begin{array}{l}\text { Integrated Air and Missile } \\
\text { Defense Enhancements } \\
\text { (IAMD) }\end{array}$ & $\begin{array}{l}\text { Providing increased/persistent ballistic/ } \\
\text { cruise missile and unmanned aircraft } \\
\text { surveillance facilities. Develops integrated } \\
\text { air and missile defense architecture for } \\
\text { EUCOM through modeling, simulation, } \\
\text { and interoperability with partner nations } \\
\text { and allies }\end{array}$ & $\$ 3.3$ million \\
\hline Intelligence Enhancements & $\begin{array}{l}\text { Providing ISR capability to enhance } \\
\text { indications \& warning and interoperability }\end{array}$ & $\$ 41.9$ million. \\
\hline $\begin{array}{l}\text { Navy Theater Anti-Submarine } \\
\text { Warfare }\end{array}$ & $\begin{array}{l}\text { Supports EUCOM operations through } \\
\text { Integrated Undersea Surveillance System } \\
\text { (IUSS) infrastructure improvement, } \\
\text { operational support, and battlespace } \\
\text { preparation }\end{array}$ & $\$ 85.2$ million \\
\hline $\begin{array}{l}\text { Marine Corps Rotational Force } \\
\text { Support }\end{array}$ & $\begin{array}{l}\text { Enables Marine Corps rotational forces to } \\
\text { increase scope of engagements with NATO } \\
\text { allies }\end{array}$ & $\$ 29$ million \\
\hline $\begin{array}{l}\text { Air Force Retain Air } \\
\text { Superiority Presence }\end{array}$ & $\begin{array}{l}\text { Supporting increased EUCOM missions } \\
\text { by retaining F-15C/D aircraft in 493rd } \\
\text { Fighter Squadron at Royal Air Force Base } \\
\text { Lakenheath. Provides funding for support } \\
\text { squadron operations and weapons system } \\
\text { sustainment }\end{array}$ & $\$ 106$ million \\
\hline $\begin{array}{l}\text { Air Force Intelligence } \\
\text { Enhancements }\end{array}$ & $\begin{array}{l}\text { Providing ISR Capability to enhance } \\
\text { indications and warning, intelligence } \\
\text { preparation of the operational } \\
\text { environment, providing intelligence data } \\
\text { via cross domain solutions including } \\
\text { Remotely Piloted Aircraft (RPA) } \\
\text { operations }\end{array}$ & $\$ 72.4$ million \\
\hline $\begin{array}{l}\text { Persistent Mobility Air Force } \\
\text { (MAF) Capability }\end{array}$ & $\begin{array}{l}\text { Continued MAF training and exercises } \\
\text { with various European countries }\end{array}$ & $\$ 9.6$ million \\
\hline $\begin{array}{l}\text { Defense-Wide Intelligence } \\
\text { Enhancements }\end{array}$ & $\begin{array}{l}\text { Maintaining dedicated analytic support to } \\
\text { provide timely intelligence and warning } \\
\text { along with exercise planning. Respond } \\
\text { to the rapidly changing theater security } \\
\text { environment and design tailored partner } \\
\text { exercises }\end{array}$ & $\$ 58.32$ million \\
\hline $\begin{array}{l}\text { Defense-Wide Intelligence } \\
\text { Enhancements for SOF }\end{array}$ & $\begin{array}{l}\text { Supporting efforts to build partnership } \\
\text { capacity and enhance SOF ability to } \\
\text { advise, assist, and train allies and partner } \\
\text { nations while simultaneously integrating, } \\
\text { collaborating, and synchronizing analytical } \\
\text { and intelligence operational requirements }\end{array}$ & $\begin{array}{l}\$ 27.1 \text { million (U.S. } \\
\text { Department of Defense, } \\
\text { Office of the Under } \\
\text { Secretary of Defense } \\
\text { (Comptroller) 2018, } \\
\text { pp. 2-7, Deni 2019, } \\
\text { pp. 92-103) }\end{array}$ \\
\hline
\end{tabular}


It remains to be seen to what extent Congress will fund DOD EDI requests. Nevertheless, the fact that the DOD is seeking significant increases in funding for EDI is an unequivocal demonstration of the Trump Administration's commitment to enhancing Baltic security by increasing tangible military assistance to NATO and partner countries in the Baltic region. The spending data presented here reflects the Trump Administration's intent to increase multispectrum defense capabilities in the Baltic.

\section{U.S. Military Assessments}

Various U.S. military branches also recognize the importance of the Baltic to emerging U.S. national security interests, with this being reflected in their analyses of European geopolitical trends since 2014. A 2016 compilation published by National Defense University Press noted that Russian leaders could engage in military intervention to "protect" Russian minorities in neighboring states such as the Baltics, that Russian territorial seizure of territory in the Baltics would impose a military escalation burden on the United States including using nuclear weapons, that NATO countries must strike a delicate balance between reassuring Baltic allies and deterring Russian miscalculation while also calming tensions, and noting that Russia has recently deployed short-range SS-26 Iskander ballistic missiles to Kaliningrad adjacent to the Baltics. This work asserted that Russian attempts to destabilize the Baltics with a Crimean variant hybrid operation could result in NATO's Article 5 being invoked, that Russia could overrun the Baltic countries within 48-72 hours but with the price of prompting a NATO response that Moscow could not maintain and shake Finnish and Swedish neutrality, that NATO battalions should have forward-based ground units possessing short-range air defense capability and the ability to eliminate offensive Russian military action from Putin's strategic calculus, that Russian air defenses at Kaliningrad, Severomorsk, and St. Petersburg cover airspace encompassing and endangering Finland, the Baltic States, northern and southern Sweden, northern Norway, Poland, and eastern Germany, and the belief of Nordic states that hybrid war in the Baltics is the most likely regional flashpoint between the West and Russia (Charting a Course: Strategic Choices for a New Administration 2016, pp. 4, 103, 209, 238, 240-241, 360).

Air Force analysis of Baltic security stresses that NATO Air Forces and the U.S. Air Force must quickly adapt to evolving strategic and technological realities including planning 
for air operations against a technologically advanced opponent like Russia. Such planning involves defending Estonia, Latvia, and Lithuania, recognizing that Russia is militarily at its strongest point since the Cold War, spreading NATO air assets to secondary airfields with pre-positioned fuel and munitions, and recognizing the strategic importance of Kaliningrad in relation to Lithuania. It also notes that Baltic region airfields risk attack from Russian SU-24 fighters employing precision or unguided air-to-surface ordnance, that an SU-24 flying at low-altitude attack profile speed would be over Estonia's Ämari Air Base ten minutes after crossing the Russo-Estonian border, and that Russian Surface to Air Missiles (SAM) such as the S-300 and S-400 could acquire and engage aircraft over eastern Estonia and Latvia (Clem, pp. 74-86).

Another Air Force assessment produced the following table estimating how many Russian air strikes would occur in the first three days of a military operation against the Baltics:

Table 4. Potential Russian Air Strikes in the First Three Days of Military Operations Against the Baltics

\begin{tabular}{|l|l|l|l|l|}
\hline Day & Number of Massed Strikes & $\begin{array}{l}\text { Percent Air } \\
\text { Superiority }\end{array}$ & $\begin{array}{l}\text { Percent Support } \\
\text { Ground Troops }\end{array}$ & Percent Isolate Battlefield \\
\hline 1 & 2 & Up to 70 & Up to 30 & - \\
\hline 2 & $1-2$ & Up to 50 & Up to 30 & Up to 20 \\
\hline 3 & 1 & Up to 30 & - & $\begin{array}{l}\text { Up to } 70 \text { (McCabe 2016, } \\
\text { p. 69) }\end{array}$ \\
\hline
\end{tabular}

This work also hypothesized that primary Russian Air Force missions during an attack against the Baltics would include:

- Repelling the first surprise air-missile strike to permit mobilizing and strategically deploying Russian armed forces and transitioning the government to a wartime footing.

- Inflicting damage on the enemy's main body by coordinated defense force operations against offensive aerospace weapons in flight and against strike forces including aircraft carriers and enemy command centers.

- Providing air cover and support for defensive military operations to repel enemy land and naval force invasions.

- Supplying air cover and support for ground units to support their seizing the strategic initiative by conducting defensive and counteroffensive operations. 
- Reserving the right to use nuclear weapons if the Russian state's existence is considered threatened by conventional attack with Russian military doctrine including the concept that a limited nuclear strike can force an enemy to "deescalate" an attack (McCabe 2016, pp. 70-71).

Another writer in an Air Force publication stressed that whether or not Russia has territorial designs on the Baltic states, it is essential for the West to act to limit Russian actions toward the Baltic and elsewhere and that strengthening NATO's deterrent posture is critically important. Specific steps in this regard include ensuring that NATO forces can survive and fight in an environment of limited Russian nuclear escalation, increasing the active and passive defense of key NATO nodes and assets against conventional and nuclear strike, and ensuring the capability to penetrate advanced Russian systems such as the S-500 missile (Payne 2017, pp. 17, 19-20).

Since Army forces will bear a significant percentage of the burden in Baltic combat operations against Russia, their analyses of this theater of operations are particularly insightful. The possibility that the condition of Russian ethnic minorities in Baltic states and other former Soviet republics could be used as a pretext for Russian military intervention is discussed in the Army's Military Review journal in 2018 (Sencerman 2018, pp. 41-49, Thornton and Karagiannis 2016, pp. 331-351). The role of Belarus involving its geographic proximity to the Baltics and its occasionally problematic relationship with Russia, which may complicate Russian military operations against the Baltics, has also been scrutinized in Army assessments (Lanoszka 2018, pp. 75-84).

The U.S. Army has also conducted exercises in the Baltic countries to signal Moscow of NATO willingness and capacity to defend its NATO partners. These exercises include Operation Saber Strike 2017 in Estonia, Latvia, Lithuania, and Poland which served as a single tactical action covering operational, strategic, and tactical aspects of war. Saber Strike involved a multinational air assault, attack on an objective, and implementing forward lines of passage in southern Lithuania while also demonstrating a combined force's ability to executive a decisive tactical action, sequenced in time, space, and purpose conjoined with other tactical actions supporting an operational plan aimed at creating theater strategic effect. The Suwalki Gap in southern Lithuania, adjoining Poland, is a narrow and tough to defend 100 kilometer land gap with forests and marshes connecting Lithuanian and Polish border regions with the Baltic countries between Belarus and Russia's Kaliningrad exclave which could become a combat fulcrum in any conflict between NATO and Russia. Its elevation ranges from sea level to 309 meters 
above sea level, its forests are difficult to navigate due to the high density of rivers, lakes, and channels, and a limited road network. The Gap's temperature ranges from $-4.4^{\circ} \mathrm{C}$ in January (reaching as low as $-30^{\circ} \mathrm{C}$ ) to a summer average of $17.4^{\circ} \mathrm{C}$ (reaching as high as $34.9^{\circ} \mathrm{C}$ ). This region has been historically contested and fought over by Germany, Poland, and Russia during the two world wars (Kemper et al. 2018, pp. 1-13, Geiger 2017, pp. 1-2, Parafianowicz 2017, pp. 3-20).

Project 1721, a 2017 U.S. Army War College analysis of Baltic security issues, is a particularly detailed and insightful analytical compendium on Russian European strategy and how to use U.S. landpower to counter Russian aspirations for regional hegemony. Written by a multinational collaboration of military professionals, Project 1721 describes how Russian strategic interest in the Baltic dates back to the rule of Peter the Great and the Great Northern War of 1700-1721 partially symbolized by the transfer of Russia's capital from Moscow to St. Petersburg. This work stresses that any effort desirous of providing strategic and operational assurance to the Baltics and deterring Russia must include diplomatic, informational, military, and economic (DIME) power instruments. It also stresses that a successful counter-Russian strategy must incorporate air, cyber, land, sea, and space power along with the participation and support of NATO allies and partners (Mastriano 2017, Frost 2000).

This work describes Russian objectives toward the Baltics as including building a land bridge with Kaliningrad, ensuring full access to and control of the Baltic Sea, restoring the former Soviet Union and Russian Federation's western boundaries, and causing NATO's collapse to restore Russia's European influence. It maintains that Moscow believes a limited intervention or disguised Baltic operation might be worth risking to test NATO's unity, stresses that Russia may use economic, financial, information, and political leverage to gain international influence, acknowledges that Russian military doctrine considers NATO's expanding military infrastructure toward Russia as a military danger, and that the Gerasimov Doctrine may see Russia employ non-military measures to disrupt opposition political decision-making processes and weakening the military and political unity of NATO opponents (Mastriano 2017, pp. 42-46).

Recommendations for dealing with Russian threats prescribed by Project 1721 include enhancing NATO's early warning capability by developing a robust and early warning Baltic region intelligence capability commanded by a U.S. Army Colonel with extensive intelligence and NATO experience; increasing the size, survivability, and mobility of Baltic armed forces so they can respond to conventional and unconventional threats 
to create strategic depth including securing vital infrastructure; Baltic states building enhanced special forces capability which is interoperable with NATO special forces which are also positioned in ethnic Russian zones to detect and counter Moscowinspired separatist movements; building a forward NATO presence in the Baltics including stationing one brigade in each Baltic nation to increase Moscow's difficulty in attacking these countries; and holding annual training exercises in the Baltics in which forces arrive from Europe and North America to demonstrate a quick response to threats to Eastern European countries (Mastriano 2017, pp. 132-136).

An essay in a Marine Corps publication stressed that Baltic security forces must be able to credibly deter Russian ambitions, NATO partners must build a security network between High North members and partners to enhance efficiencies and ensure unity of effort if there's a military confrontation with Russia, and NATO deterrence being designed to a quick Russian victory. This treatise acknowledged NATO's limited Russian attack response time due to the lack of natural boundaries and the short distance between Russia and the Baltic states. It stressed that Moscow would use hybrid war and provokatsiya (provocation) to achieve objectives short of all-out war; that the west should seek to deny Russia a quick victory by recognizing that it will take approximately 10 days for NATO heavy armor to reinforce the Baltics from Grafenwöhr, Germany; that Baltic populations will bear the initial brunt of casualties and have to use guerilla tactics to delay the Russians, and that developing defense layers below the nuclear threshold is the best way to deter and defeat Russian aggression (Goldberg 2017, pp. 15-39).

U.S. Navy assessments of Baltic security matters include a U.S. Naval War College Russian Maritime Studies Institute (RMSI) translation of Russia's 2015 Maritime Doctrine. Where the Baltic Sea is concerned, the key objectives of this document stress Moscow's intention to:

- Develop coastal and port infrastructure, renew oceanic and riverine lanes for ship navigation, and develop an undersea pipeline for export and supplying energy to Kaliningrad;

- Develop military capabilities and the Baltic Fleet's military installation;

- Develop a fleet capable of achieving national maritime policy objectives; and;

- The Navy working with the Federal Security Service to accomplish national objectives (Maritime Doctrine of the Russian Federation 2015, pp. 18-20).

A 2016 RMSI analysis noted that the Russian threat to the Baltics has increased exponentially since 2008, that NATO must develop the ability to decisively break 
through Russian A2/AD capabilities in Central Europe, and the Baltics, develop a robust Baltic Sea naval presence, and factor the Baltic into NATO maritime strategy; and that $71 \%$ of Naval War College (NWC) faculty rated the possibility of a Russian military move against the Baltics as low or very low with $18 \%$ of NWC faculty rating it as high or very high (Sense of the Faculty... 2016, pp. 2, 9, Lundqvist and Weiden 2015, pp. 42-48).

The Office of Naval Intelligence (ONI) stresses that Russian interest in the Baltic dates back to the 9th century as part of riverine trade connecting the Baltic and Black Seas, the 1703 establishment of Russia's Baltic Fleet, this fleet's combat readiness at the onset of Operation Barbarossa in 1941, and the Baltic Fleet containing the following order of battle in 2015: 2 submarines, 2 guided missile destroyers, 1 guided missile frigate, 6 frigates, 11 guided missile patrol gun boats, 7 patrol gun boats, 4 landing ship tanks, and 2 utility landing craft. Russia also possesses a Baltic shipyard in St. Petersburg, the F.F. Ushakov Baltic Naval Institute is located in Kaliningrad, and on July 6, 2015, Russian Navy Commander-in-Chief Admiral Viktor Chirkov declared that "the nuclear submarine fleet is the priority in the navy shipbuilding program." The importance of submarines in the Baltic as a source of potential combat operations and as a gateway for Russian submarines desiring to reach the Atlantic remains of ongoing strategic importance. A chart accompanying this $\mathrm{ONI}$ assessment projected continuing growth in the number of Russia's Baltic Sea Fleet ships to 2030. The May 4, 2018 reestablishment of the 2nd Fleet by the Chief of Naval Operations whose area of operations will include the North Atlantic also demonstrates tangible U.S. commitment to countering Russian naval assertiveness (U.S. Chief of Naval Operations 2018, p. 1, U.S. Office of Naval Intelligence 2015, pp. xiii, xvi-svi, 16-17, 20, 30, Bruns 2019, pp. 117-132).

\section{Policy Research Institution Analysis}

The Baltic's increasing importance has been analyzed intensively by U.S. and international nongovernmental public policy research institutions since 2014. In 2016, the Center for a New American Security (CNAS) conducted an Assured Resolve Exercise simulation involving a hypothetical Russian attack against NATO. Assured Resolve found that the traditional balance between deterrence, response, and escalation was dangerously offset with U.S. and Baltic members being more willing to quickly invoke NATO's Article 
5, while other NATO members were more cautious in their response. This assessment also found NATO lacks key capabilities to combat Russian aircraft and other A2/AD capabilities, and that Finland and Sweden need to decide whether to join NATO and how to respond to requests they may receive from the U.S. if Washington and other NATO countries react aggressively to Russian aggression (Smith and Hendrix 2016, pp. $5,7,15-16)$.

A March 2018 Center for Strategic and International Studies (CSIS) analysis determined that Russia imposes three Maritime Domain Awareness (MDA) challenges in Northern European waters including maritime hybrid warfare involving civilian ships, deniable forces including amphibious and light infantry, and Moscow's well-developed and diverse seabed warfare force; cyber and electronic warfare whose advanced capabilities can hinder civilian and military information dissemination and gathering; and longrange strike capabilities including precision munitions and Air Force capabilities in the Kola Peninsula and Kaliningrad giving Russia the option of placing them on naval vessels in the Barents of White Seas and the capability to strike Northern European targets.

CSIS report recommendations include:

\section{Table 5. CSIS Report Recommendations for Countering Russian Military Capabilities}

\begin{tabular}{|l|}
\hline $\begin{array}{l}\text { Creating a Baltic SEA MDA Analytic Center at the Baltic Maritime Component Command in Rostock } \\
\text { to analyze, collect, diffuse, and disseminate Baltic MDA information. }\end{array}$ \\
\hline Develop a training course for military intelligence officers on Baltic MDA analysis best practices. \\
\hline $\begin{array}{l}\text { Integrate subsurface sensors and antisubmarine warfare buoys and associated acoustic processing } \\
\text { systems. }\end{array}$ \\
\hline Acquire significant stockpiles of advanced sonobuoys and associated acoustic processing systems \\
\hline $\begin{array}{l}\text { Create resilient commercial systems capable of reinforcing air and sea traffic relying on radar, GPS, VHF } \\
\text { radio, and UHF radio systems in the congested Baltic Sea region. }\end{array}$ \\
\hline $\begin{array}{l}\text { Ensure civil-military collaboration. Northern European nations need to ensure standardized tactics, } \\
\text { techniques, and procedures for MDA activities between civil and military authorities including evolving } \\
\text { relevant MDA capabilities to military operational control during a crisis. }\end{array}$ \\
\hline $\begin{array}{l}\text { Developing capabilities for small signature detection including Russian combat swimmers, amphibious } \\
\text { special operations forces, and other deniable military capabilities. }\end{array}$ \\
\hline $\begin{array}{l}\text { Acquiring a range of aerial, surface, and sub-surface unmanned vehicles including aircraft and counter- } \\
\text { mine unmanned surface vessels. }\end{array}$ \\
\hline $\begin{array}{l}\text { Acquiring mobile air surveillance radar capabilities to maintain persistent coverage of Baltic and North } \\
\text { Sea airspace. }\end{array}$ \\
\hline $\begin{array}{l}\text { Utilize emerging space surveillance capabilities with high revisit rates to monitor ship movements } \\
\text { (Metrick and Hicks 2018, pp. IV, 42-47). }\end{array}$ \\
\hline
\end{tabular}


The 2018 Military Balance report from the International Institute for Strategic Studies (IISS) notes significant disparity between Baltic countries and Russian military forces. Estonian military forces include 6,600 active duty personnel and 15,800 Defence League personnel; Latvian active duty personnel number 5,310 and 7,850 reserves; and Lithuanian active duty strength is 18,350 and its reserve strength is 6,700. Russia's Army alone includes 280,000 active duty personnel with many operationally based at St. Petersburg's Western Military Headquarters. Russian forces adjacent to the Baltic nations are estimated to contain 22 battalions against Baltic and EDI deployed forces (Military Balance 2018, pp. 98-99, 122, 124, 192, Shlapak and Johnson 2016, p. 4).

A 2016 report by Estonia's International Centre for Defence and Security (ICDS) asserted that NATO must deploy a "battalion-plus' battle group with enablers and force multipliers in each Baltic country, that there should be an additional U.S. Army battalion in each of these countries, and advocated strengthening NATO's nuclear deterrent by informing Moscow that its using sub-strategic nuclear weapons to de-escalate conflict would be a major escalation warranting a nuclear response (Clark et al. 2016, pp. 6-7). Protecting power grids from Russian cyberattack and other hostilities by moving Baltic country power grids to Nordic or European continental grids was also recommended in a 2018 ICDS report (Tuohy, Jermalaviciius and Bulakh 2018).

The most troubling aspect of Baltic security was demonstrated by a 2016 Rand Corporation report documenting 2014-2015 war games on a Russian invasion of the Baltics. This assessment maintained Russian forces could reach Riga and Tallinn within 60 hours and that a bloody counteroffensive with potential escalatory risk would be required to liberate the Baltics, and that conceding temporary military defeat would have disastrous consequences for the Baltic countries and NATO alliance. Report recommendations included increasing NATO forces to seven brigades, including three heavy armored brigades sufficiently reinforced with airpower, land-based fire support and other enablers could help prevent rapid conquest of the Baltics, and that developing this deterrent would have annual costs of $\$ 2.7$ billion which must be seen in the context of annual NATO defense spending exceeding \$1 trillion (Shlapak and Johnson 2016, pp. 1-2). 


\section{Conclusions}

Recent and ongoing U.S. government and public policy literature and political debate recognizes that Russian aggression in Georgia and Ukraine also applies to the Baltic region. All NATO countries must acknowledge the reality that a new Cold War exists with a revisionist Russia. The U.S., its NATO allies, and Nordic partner countries like Finland and Sweden must accept this inescapable geopolitical reality and bluntly inform domestic public opinion that continuing increases in military spending and force deployment in the Nordic and Baltic regions will be essential for the forseeable future. Continuing military exercises must occur in Poland and the Baltic countries and include drills to defend these countries and simulate exercises to capture Kaliningrad and detach it from Russia if military conflict occurs. Air forces must continually patrol Baltic skies, surface and sub-surface naval forces must continually monitor Russian maneuvers, and intelligence capabilities need to be strengthened against Russian active measures and provocations across the entire combat spectrum including space. Forces executing these countermeasures must be given liberal rules of engagement in the event of hostile interaction with Russian or Russian-allied forces (Ringsmose and Rynning 2017, pp. 129-146, Götz 2019, pp. 99-117).

These countries also need to strengthen their cyber resilience and critical infrastructure resilience to counteract Russian attempts to disable these assets which are critical to multiple civilian and military activities. Adroitly responding to and counteracting Russian attempts to influence and manipulate public opinion must also be ongoing efforts of the U.S. and its allies. There must be continuing development of allied ballistic missile defense and precision-guided munitions capabilities to counter ongoing Russian military technological advances. Installing anti-personnel land mines in these countries Russian border regions should also be considered. The U.S. and its allies need to upgrade their military doctrine to emphasize their ability and willingness to take decisive measures to defeat covert or overt Russian military and non-military action against the Baltics. Ongoing defense spending increases by Baltic region countries must be sustained to cope with the continually evolving Russian threat. The June 12, 2019 announcement that Poland will purchase 32 F-35 Joint Strike Fighters and that the U.S. will send 1,000 troops to Poland at a White House meeting between President Trump and Polish President Andrzej Duda indicates some level of commitment to increasing NATO resolve toward Russia. 
There must be continuing dialogue with Russia to demonstrate western willingness to international opinion to keep hostilities from inadvertently breaking out. This communication must be coordinated and candid across the NATO alliance and from Finland and Sweden to ensure that Moscow does not attempt to exploit potential policy differences between these countries. Both Helsinki and Stockholm need to abandon their Cold War era morally relativistic neutrality and join NATO as soon as possible to enhance alliance diplomatic solidarity and military interoperability. Moscow must be repeatedly warned in public and confidential communications that any attempt to militarily invade the Baltics or subvert these countries through active measures will result in devastating diplomatic, economic, military, and political consequences for the Kremlin. Unflinching realism, diplomatic cohesion, and ongoing efforts to develop and sustain credible military forces capable of deterring then defeating Russia if military confrontation occurs must be hallmark characteristics of U.S. and western policy toward Moscow. Overcoming the partisan divisions caused and lingering from Russian interference in the 2016 U.S. election presently makes achieving greater Baltic policy cohesion extremely difficult. Following many of the recommendations contained in the analyses documented in this assessment will be critical if protecting Baltic nations' hard-won freedom and independence is to be maintained. The Baltic needs to rank at least as highly in U.S. and NATO strategic calculation as other strategically critical regions including China and the Western Pacific, North Korea, Iran, the Middle East, and South Asia. Actions over the forthcoming longue durée will determine if the U.S. and its allies are successful in defending Baltic freedom and security (Béraud-Sudreau 2019, pp. 94-122, Hamilton 2019, p. 334-348, President Donald Trump 2019, p. 21).

\section{References}

Ǎtland, K., 2016. North European Security After the Ukraine Conflict. Defense \& Security Analysis, 32 (2), 163-176. https://doi.org/10.1080/14751798.2016.1160404.

Béraud-Sudreau, L. and Giegerich, B., 2018. NATO Defence Spending and European Threat Perceptions. Survival: Global Politics and Strategy, 60 (4), 53-74; https://www.tandfonline. com/doi/full/10.1080/00396338.2018.1495429.

Bruns, S., 2019. From Show of Force to Naval Presence and Back Again: The U.S. Navy in the Baltic, 1982-2017. Defense \& Security Analysis, 35 (2), 117-132. https://doi.org/10.1080/1 4751798.2019.1600799

Chapman, B., 2016. U.S. Congressional Committee Hearings on Korea During the 113th Congress 2013-2014: Overseeing Multifaceted Aspects of Washington's Peninsular Interests. 
The Korean Journal of Defense Analysis [online]. 28 (1), 85-86. Available from: https://docs. lib.purdue.edu/lib_fsdocs/130/ [Accessed 3 May 2019].

Hooker, Jr., R., D., ed., 2016, Charting a Course: Strategic Choices for a New Administration. Washington: National Defense University Press. Available from: http://purl.fdlp.gov/GPO/ gpo76990.

Clark, W., Luik, J., Ramms, E. and Shirreff, R., 2016. Closing NATO's Baltic Gap [online]. International Centre for Defence and Security, Tallinn. Available from: https://icds.ee/wpcontent/uploads/2015/ICDS_Report-Closing_NATO_s_Baltic_Gap.pdf [Accessed 21 May 2019].

Clem, R.S., 2016. Geopolitics and Planning for a High End Fight: NATO and the Baltic Region. Air and Space Power Journal [online]. 30(1), 74-86. Available from: http://www.airuniversity. af.mil/Portals/10/ASPJ/journals/Volume-30_Issue-1/V-Clem.pdf [Accessed 17 May 2019].

Congressional Record, 2015. 161 (89)(June 4): p. S3766 [online]. Available from: https://www. govinfo.gov/content/pkg/CREC-2015-06-04/pdf/CREC-2015-06-04-senate.pdf [Accessed 3 May 2019].

Congressional Record, 2017. 163 (54)(March 28): H2468 [online]. Available from: https://www. govinfo.gov/content/pkg/CREC-2017-03-28/pdf/CREC-2017-03-28-house.pdf [Accessed 3 May 2019].

Congressional Record, 2017. 163(86)(May 18): E669 [online]. Available from: https://www. govinfo.gov/content/pkg/CREC-2017-05-18/pdf/CREC-2017-05-18-extensions.pdf [Accessed3 May 2019].

Council of the Baltic Sea States, 2017 [online]. CBSS, Stockholm. Available from: http://www. cbss.org/council/; [Accessed 2 May 2019].

Deni, J.R., 2019. Is NATO's Enhanced Forward Presence Fit for Purpose? Orbis, 63 (1), 92-103. https://www.doi.org/10.1016/j.orbis.2018.08.002.

Emmott, R., and Ali, I., 2018. U.S. Pushes NATO to Read More Forces to Deter Russian Threat [online]. Reuters. Available from: https:/www.reuters.com/article/us-nato-russia/u-s-pushesnato-to-ready-more-forces-to-deter-russian-threat-idUSKCN1J11L4; [Accessed 6 August 2019].

Frost, R.L., 2000. The Northern Wars: War, State, and Society in Northeastern Europe, 1558-1721. London: Routledge.

Geiger, J., 2017. eFP Battle Group Poland Crosses the Suwalki Gap into Lithuania, Washington: U.S. Army [online]. Available from: https://www.army.mil/article/189581/efp_battle_ group_poland_crosses_the_suwalki_gap_into_lithuania [Accessed 20 May 2019].

Giguère, S., ed., Baltic Partnerships: Integration, Growth and Local Governance in the Baltic Sea Region. 2007, Paris: OECD.

Goldberg, A.J., 2017. Baltic Flashpoint: Collective Defense for the Twenty-First Century. In Slater, M.R., Purcell, M., and Del Gaudio, A.M., eds. Considering Russia: Emergence of a New Peer Competitor. Quantico: Marine Corps University Press [online]. Available from: http://purl.fdlp.gov/GPO/gpo83374 [Accessed 20 May 2019].

Götz, E., 2019. Enemy at the Gates: A Neoclassical Realist Explanation of Russia's Baltic Policy. Foreign Policy Analysis, 15 (1), 99-117. https://doi.org/10.1093/fpa/orx11

H.R. 2820, 115th Congress, 1st Session. 2017, Fight Russian Corruption Act [online]. Available from: https:/www.govinfo.gov/content/pkg/BILLS-115hr2820ih/pdf/BILLS115 hr2820ih.pdf. 
History of Bills, 163 [online]. Available from: https:/www.govinfo.gov/content/pkg/HOB2017/html/HOB-2017-hr2820.htm [Accessed 16 May 2019].

Hamilton, R.E., 2019. Russia's Attempts to Undermine Democracy in the West: Effects and Causes. Orbis, 63 (3), 334-348 doi: 10.1016/j.orbis.2019.05.009.

Herzog, S., 2011. Revisiting the Estonian Cyber Attacks: Digital Threats and Multinational Responses. Journal of Strategic Security, 4 (2), 49-60 [online]. Available from: https:// scholarcommons.usf.edu/jss/vol4/iss2/4/ [Accessed 11 June 2019].

Joint Statement: A Declaration to Celebrate A 100 Years of Independence of Estonia, Latvia, and Lithuania and Renewed Partnership, 2018 [online]. Daily Compilation of Presidential Documents. Available from: https://www.govinfo.gov/content/pkg/DCPD-201800213/ pdf/DCPD-201800213.pdf [Accessed 18 June 2019].

Joint Statement of the United States-Nordic Leaders Summit, 2016 [online]. Daily Compilation of Presidential Documents. Available from: https://www.govinfo.gov/content/pkg/DCPD201600314/pdf/DCPD-201600314.pdf [Accessed 3 May 2019].

Kemper, C., Helgestad, J., Colvin, N, and Cox, S., 2018. Design to Execution Into the Suwalki Gap [online]. Military Review. Available from: http://www.armyupress.army.mil/Journals/ Military-Review/Online-Exclusive/2018-OLE/Design-to-Execution/ [Accessed 20 May 2019].

Kragh, M and Åsberg, S., 2017. Russia’s Strategy for Influence Through Public Diplomacy and Active Measures: The Swedish Case. Journal of Strategic Studies, 40 (6), 777-816. http://doi. org/10.1080/01402390.2016.1273830.

Kuhn, U., 2018. Preventing Escalation in the Baltics: A NATO Playbook. Carnegie Endowment for International Peace, Washington, DC [online]. Available from: https://carnegieendowment. org/2018/03/28/preventing-escalation-in-baltics-nato-playbook-pub-75878 [Accessed 2 May 2019].

Kyle, J., 2019. Contextualizing Russia and the Baltic Sea States. Orbis, 63 (1), 104-115. https:// doi.org/10.1016/j.orbis.2018.12.004.

Lanoszka, A., 2018. The Belarus Factor in European Security. Parameters, 47(4), 75-84 [online]. Available from: https://ssi.armywarcollege.edu/pubs/Parameters/issues/Winter_2017-18/9_ Lanoszka.pdf [Accessed 20 May 2019]

Lanoszka, A. and Hunzecker, M.A., 2016. Confronting the Anti-Access/Area Denial and Precision Strike Challenge in the Baltic Region. The RUSI Journal, 161 (5), 12-18. https:// doi.org/10.1080/03071847.2016.1253367.

Lundqvist, S. and Weiden, J.J., 2015. The New U.S. Maritime Strategy: Implications for the Baltic Sea Region. The RUSI Journal, 160 (5), 42-48; https://doi.org/10.1080/03071847.2 015.1122986

McCabe, T.R., 2016. The Russian Perception of the NATO Aerospace Fall Threat: Could It Lead to Preemption? Air and Space Power Journal, 30(3), 70-71 [online]. Available from: http://www.airuniversity.af.mil/Portals/10/ASPJ/journals/Volume-30_Issue-3/V-McCabe. pdf [Accessed 17 May 2019].

McGuiness, D., 2017. How a Cyber Attack Transformed Estonia [online]. BBC News. Available from: http://www.bbc.com/news/39655415 [Accessed 2 May 2019].

McNamara, E. M., 2017. Between Trump's America and Putin's Russia: Nordic-Baltic Security Relations Amid Transatlantic Drift. Irish Studies in International Affairs, 28 (2), 73-98; DOI: 10.3318/isia.2017.28.2. 
Maritime Doctrine of the Russian Federation, 2015. [online]. Russian Maritime Studies Institute. Available from: https://nnnlgwick.blob.core.windows.net/portals/0/NWCDepartments/ Russia\%20Maritime\%20Studies\%20Institute/Maritime\%20Doctrine\%20TransENGrus_ FINAL. pdf?sr=b\&si=DNNFileManagerPolicy\&sig=fqZgUUVRVRrKmSFNMOj\%2FNa RNawUoRdhdvpFJj7\%2FpAkM\%3D [Accessed 21 May 2019].

Metrick, A. and Hicks, K.J., 2018. Contested Seas: Maritime Domain Awareness in Northern Europe [online]. Center for Strategic and International Studies. Available from: https://csisprod.s3.amazonaws.com/s3fs-public/publication/180328_MetrickHicks_ContestedSeas_ Web.pdf?AaSGbCYstp_dVE22M_UODVuJvVS0_mkM [Accessed May 21, 2019].

Milevski, L., 2018. The West's East: Contemporary Baltic Defense in Strategic Perspective. New York : Oxford University Press.

Military Balance, 2018. London : International Institute of Strategic Studies.

Mölder, H., 2011. The Cooperative Security Dilemma in the Baltic Sea Region. Journal of Baltic Studies, 42 (2), 143-168. https://doi.org/10.1080/01629778.2011.569063.

Munoz, C., 2019. NATO Tackles Growing Russia, China Threat With New Military Strategy [online]. Washington Times. Available from: https://www.washingtontimes.com/news/2019/may/29/ joseph-dunford-nato-military-strategy-tackle-russi/; [Accessed 6 August 2019].

North, M.N., and Kronenberg, K., 2016. The Baltic: A History. Cambridge : Harvard University Press.

North Atlantic Treaty Organization, 2018. NATO Response Force/Very High Readiness Task Force [online]. NATO. Available from: https://shape.nato.int/nato-response-force--very-highreadiness-joint-task-force [Accessed 6 August 2019].

North Atlantic Treaty Organization, 2019a. Enhanced Forward Presence. NATO [online]. Available from https://shape.nato.int/efp [Accessed 6 August 2019]

North Atlantic Treaty Organization, 2019b. NATO Air Policing [online]. NATO [online]. Available from: https://ac.nato.int/page5931922/-nato-air-policing [Accessed 6 August 2019].

North Atlantic Treaty Organization. What is NATO? 2017 [online]. NATO. Available from: https://www.nato.int/nato_static_fl2014/assets/pdf/pdf_publications/20171117_ WhatIsNATO_en.pdf [Accessed 2 May 2019].

Parafianowicz, R., 2017. The Military-Geographical Significance of the Suwałki Gap. Security and Defence Quarterly, 20(4), 3-20; https://doi.org/10.5604/01.3001.0011.7839 [Accessed 21 May 2019].

Payne, K. B., 2017. Thinking Anew About U.S. Nuclear Policy Toward Russia. Strategic Studies Quarterly, 11 (2), 17, 19-20 [online]. Available from: http://www.airuniversity.af.mil/ Portals/10/SSQ/documents/Volume-11_Issue-2/Payne.pdf [Accessed 20 May 2019].

President Donald Trump, 2019. Remarks by President Trump and President Duda of the Republic of Poland Before Bilateral Meeting. The White House, Washington, DC [online]. Available from: https://www.whitehouse.gov/briefings-statements/remarks-president-trump-presidentduda-republic-poland-bilateral-meeting-2/ [Acessed 18 June 2019].

The President's News Conference with President Toomas Hendrik Ilves of Estonia in Tallinn, Estonia, 2014 [online]. Daily Compilation of Presidential Documents. Available from: https://www. govinfo.gov/content/pkg/DCPD-201400638/pdf/DCPD-201400638.pdf [Accessed 2 May 2019]. 
Mastriano, D., 2017. Project 1721: A U.S. Army War College Assessment on Russian Strategy in Eastern Europe and Recommendations on How to Leverage Landpower to Maintain the Peace. Carlisle : United States Army War College Press [online]. Available from: http://purl.fdlp. gov/GPO/gpo81977 [Accessed 20 May 2019].

Public Law 113-291, Carl Levin and Howard P. Buck McKeon National Defense Authorization Act For Fiscal Year 2015 (2014). 128 U.S. Statutes at Large 3618 [online]. Available from: https://www.govinfo.gov/content/pkg/PLAW-113publ291/pdf/PLAW-113publ291.pdf [Accessed 16 May 2019].

Public Law 115-91, National Defense Authorization Act for Fiscal Year 2018. 2017. 131 U.S. Statutes at Large 1283 [online]. Available from: https:/www.gpo.gov/fdsys/pkg/BILLS115hr2810enr/html/BILLS-115hr2810enr.htm [Accessed 17 May 2019].

Remarks Following a Meeting With President Sauli Niinistö of Finland, Prime Minister Erna Solberg of Norway, Prime Minister Stefan Löfven of Sweden, Prime Minister Laws Løkke Rasmussen of Denmark, and Prime Minister Sigurour Ingi Jóhansson of Iceland. 2016 [online]. Daily Compilation of Presidential Documents. Available from: https:/www.govinfo.gov/content/ pkg/DCPD-201600313/pdf/DCPD-201600313.pdf [Accessed 2 May 2019].

Remarks in Warsaw, Poland, 2017 [online]. Daily Compilation of Presidential Documents. Available from: https://www.govinfo.gov/content/pkg/DCPD-201700453/pdf/DCPD201700453.pdf [Accessed 3 May 2019].

Ringsmose, J., and Rynning S., 2017. Now for the Hard Part: NATO's Strategic Adaptation to Russia. Survival: Global Politics and Strategy, 59 (3), 129-146. https://doi.org/10.1080/003 96338.2017.1325603

S. Res. 501: Expressing the Sense of the Senate on Russian Military Aggression. 114th Congress, 2nd Session. 2016 [online]. Available from: https://www.govinfo.gov/content/pkg/HOB2016/html/HOB-2016-sres501.htm [Accessed 3 May 2019].

Scheer, B., 2019. Trump, NATO, and the Future of Europe's Defense. The RUSI Journal, 164 (1), 10-17 https://www.tandfonline.com/doi/full/10.1080/03071847.2019.1605011.

Sencerman, Ö., 2018. Russian Diaspora as a Means of Russian Foreign Policy. Military Review, 98 (2), 41-49 [online]. Available from: http://www.armyupress.army.mil/Portals/7/militaryreview/Archives/English/Sencerman-Russian-Diaspora.pdf [Accessed 20 May 2019].

Sense of the Faculty: Russia Futures Project Summary Report, 2016 [online]. Russian Maritime Studies Institute[online].Availablefrom:https://dnnlgwick.blob.core.windows.net/portals/0/NWC_ Sense-of-the-Faculty-Report_Russia_July2016.pdf?sr=b\&si=DNNFileManagerPolicy\&sig= \%2FIbXTCgqsIHnbAcehu\%2FO18uvWJGTeozyhCx6\%2FiV8sso\%3D; [Accessed 21 May 2019].

Shlapak, D., and Johnson, M., W., 2016. Reinforcing Deterrence on NATO's Eastern Flank: Wargaming the Defense of the Baltics. Rand Corporation, Santa Monica [online]. Available from: https://www.rand.org/pubs/research_reports/RR1253.html [Accessed 21 May, 2019].

Smith, J., and Hendrix, J., 2016. Assured Resolve: Testing Possible Challenges to Baltic Security [online]. Center for a New American Security. Available from: https://s3.amazonaws.com/ files.cnas.org/documents/CNASReport-BalticTTX-160331.pdf?mtime=20160915160018 [Accessed 21 May 2019].

Stravers, A.J., 2018. Partisan Conflict Over Grand Strategy in Eastern Europe, 2014-2017. Orbis, 62 (4), 541-556 https://doi.org/10.1016/j.orbis.2018.08.002. 
Thieme, D., 2018. The Baltic, Poland, and President Trump's Warsaw Declaration. Naval War College Review [online], 71 (2), 149-153. Available from: http://digital-commons.usnwc. edu/cgi/viewcontent.cgi?article=1739\&context=nwc-review; [Accessed 3 May 2019].

Thornton, R. and Karagiannis, M., 2016. The Russian Threat to the Baltic States: The Problems of Shaping Local Defense Mechanisms. The Journal of Slavic Military Studies, 29 (3), 331351 https://doi.org/10.1080/13518046.2016.1200359.

Tuohy, E., Jermalavičius, T., and Bulakh, A., 2018. The Geopolitics of Power Grids: Political and Security Aspects of Baltic Electricity Synchronization. International Centre for Defence and Security, Tallinn [online]. Available from: https://uploads.icds.ee/ICDS_Report_The_ Geopolitics_of_Power_Grids_Tuohy_Jermalavicius_Bulakh_March_2018.pdf [Accessed 21 May 2019).

U.S. Chief of Naval Operations, 2018. CNO Announces Establishment of U.S. 2nd Fleet CNO [online]. Available from: http://www.navy.mil/submit/display.asp?story_id=105453 [Accessed 21 May 2019].

U.S. Commission on Security and Cooperation in Europe, 2017 [online]. Baltic Security After the Warsaw-NATO Summit. GPO. Available from: http://purl.fdlp.gov/GPO/gpo77052 [Accessed 3 May 2019].

U.S. Commission on Security and Cooperation in Europe, 2016. NATO's Warsaw Summit and the Future of European Security. GPO. Available from: http://purl.fdlp.gov/GPO/gpo71323 [Accessed 3 May 2019].

U.S. Congress. House Committee on Armed Services, 2017. Military Assessment of Russian Activities and Security Challenges in Europe. GPO. Available from: http://purl.fdlp.gov/GPO/ gpo87722 [Accessed 3 May 2019].

U.S. Congress. House Committee on Armed Services. Subcommittee on Tactical Air and Land Forces, 2017 [online]. U.S. Ground Force Capability and Modernization Challenges in Eastern Europe. GPO. Available from: http://purl.fdlp.gov/GPO/gpo82685 [Accessed 3 May, 2019].

U.S. Congress. House Committee on Foreign Affairs. Subcommittee on Europe, Eurasia, and Emerging Threats, 2017 [online]. U.S. Policy Toward the Baltic States. GPO. Available from: http://purl.fdlp.gov/GPO/gpo80943 [Accessed 2 May 2019].

U.S. Congress. Senate Committee on Armed Services, 2017 [online]. The North Atlantic Treaty Organization, Russia, and European Security. GPO. Available from: http://purl.fdlp.gov/ GPO/gpo87908 [Accessed 3 May 2019].

U.S. Congress. Senate Select Committee on Intelligence, 2017. Russian Intervention in European Elections [online]. GPO. Available from: http://purl.fdlp.gov/GPO/gpo86823 [Accessed 16 May 2019].

U.S. Department of Defense, 2018. Summary of the 2018 National Defense Strategy of the United States of America [online]. DOD. Available from: https://www.defense.gov/Portals/1/ Documents/pubs/2018-National-Defense-Strategy-Summary.pdf [Accessed 17 May 2019].

U.S. Department of Defense. Office of Inspector General, 2017. Evaluation of the European Reassurance Initiative [online]. Available from: https://media.defense.gov/2017/ Dec/19/2001858688/-1/-1/1/DODIG-2017-111.PDF [Accessed 16 May 2019].

U.S. Department of Defense. Office of the Under Secretary of Defense (Comptroller), 2018 [online]. European Deterrence Initiative: Department of Defense Budget Fiscal Year (FY) 2019) 
[online]. DOD Comptroller. Available from: http://comptroller.defense.gov/Portals/45/ Documents/defbudget/fy2019/fy2019_EDI_JBook.pdf [Accessed 17 May 2019].

U.S. Department of State, Bureau of Intelligence and Research, 1973. Limits in the Seas: Continental Shelf and Territorial Boundaries Poland-Soviet Union) [online]. U.S. Department of State. Available from: https://2009-2017.state.gov/documents/organization/61508.pdf; [Accessed 2 May 2019].

U.S. European Command, 2017, 2018 European Reassurance Initiative (ERI) Fact Sheet [online]. U.S. European Command Public Affairs Office [online]. Available from: https://www. eucom.mil/media-library/document/35876/2018-eri-fact-sheet [Accessed 16 May 2019].

U.S. European Command, 2019. FY2020 European Reassurance Initiative (ERI) Fact Sheet [online]. U.S. European Command Public Affairs Office [online]. Available from: https://www.eucom. $\mathrm{mil} / \mathrm{CustomSearch}$ ?query=european+reassurance+initiative+\%28ER \% 29+fact+sheet [Accessed 21 May 2019].

U.S. Government Accountability Office, 2018. Defense Budget: Obligations of Overseas Contingency Operations Funding for Operation and Maintenance Base Requirements [online]. GAO. Available from: https://www.gao.gov/assets/690/689343.pdf [Accessed 16 May 2019].

U.S. Government Accountability Office, 2017. European Reassurance Initiative: DOD Needs to Prioritize Posture Initiatives and Plan for and Report Their Future Costs [online]. GAO. Available from: https://purl.fdlp.gov/GPO/gpo87946 [Accessed 16 May 2019].

U.S. Navy Ship Encounters Aggressive Russian Aircraft in Baltic Sea, 2016 [online]. U.S. Navy. Available from: http://www.navy.mil/submit/display.asp?story_id=94170 [Accessed 2 May 2019].

U.S. Office of Naval Intelligence, 2015. The Russian Navy: A Historic Transition [online]. Office of Naval Intelligence. Available from: http://purl.fdlp.gov/GPO/gpo64244 [Accessed 21 May 2019].

U.S. Office of Naval Intelligence, 2018. Russian Navy Major Forces by Fleet (Continue) [online]. Available from: http://www.oni.navy.mil/Portals/12/Intel\%20agencies/russia/Major_ Forces_by_Fleet_Cont inue_.jpg?ver=2015-12-14-082027-470 [Accessed 21 May 2019].

Wieslander, A., 2019. What Makes an Ally?: Sweden and Finland as NATO's Closest Partners. Journal of Transatlantic Studies, 17 (2), 94-122; https://doi.org/10.1057/s42738-01900019-9.

\section{Authors:}

\section{Prof. Bert Chapman}

Government Information, History, and Political Science Librarian, Purdue University Libraries and School of Information Studies, West Lafayette, IN USA 47907-2058

(iD) https://orcid.org/0000-0002-8388-3376 